Arab World English Journal (AWEJ) Volume 12. Number3 September 2021

Pp. 257-277

DOI: https://dx.doi.org/10.24093/awej/vol12no3.18

\title{
A Pragma- Stylistic Analysis of Formal Congratulatory Letters in English and Arabic
}

\author{
Muna Y. Al-Janabi \\ Department of English, College of Languages \\ University of Baghdad, Baghdad, Iraq \\ Corresponding Author: mona.yaas1201a@colang.uobaghdad.edu.iq \\ Ibtihal M. Al-Tememi \\ Department of English, College of Languages \\ University of Baghdad, Baghdad, Iraq
}

Received: 5/6/2021

Accepted: 8/9/2021

Published: 9/24/2021

\begin{abstract}
Politeness strategies are of significant importance to maintain the face of the addressee. Senders of formal congratulatory letters seek to create a positive image in the minds of their addresses by performing particular illocutionary acts and face-saving acts (FSAs) in the form of written texts. To the best knowledge of the researcher, this topic received little attention from linguistic researchers, especially on the pragma-stylistic level. The importance of this study arises from the fact that congratulatory formal letters are an effective tool in the successful performance of foreign relations and thus deserve investigation. The current study investigates the pragmastylistic aspects of illocutionary acts and FSA Politeness Strategies in some selected English and Arabic formal congratulatory letters written by English and Arabic officials. Findings reveal that assertive constitutes the highest frequency in English data, while expressive occurs more in Arabic. Besides, the FSA politeness strategy (Use appropriate forms of address) includes most of the total frequency in both English and Arabic data, which still it appeared more in English. Additionally, (Exaggerate interest, sympathy with $\mathrm{H}$ ) comes next in Arabic, while (Be optimistic) appeared more in English. In addition, results show that exaggeration (Hyperbole) is the prevalent stylistic device used in Arabic. Arabic officials usually exaggerate the glorification of people in authoritative positions, while English high officials tend to be more moderate. The findings will be helpful in cross-cultural comparative studies and other related fields.

Keywords: congratulations, formal letters, illocutionary acts, politeness strategies, stylistic analysis
\end{abstract}

Cite as: Al-Janabi, M.Y., \& Al-Tememi, I. M. (2021). A Pragma- Stylistic Analysis of Formal Congratulatory Letters in English and Arabic. Arab World English Journal, 12 (3) 257-277.

DOI: https://dx.doi.org/10.24093/awej/vol12no3.18 


\section{Introduction}

The practice of making proper diplomatic forms of communication dates back to the early points in history when interactions between nations have assumed tremendous significance. Since then, standardized models have developed, which are commonly used by family Member States of countries in the present time (Borisova, 2013).

Congratulatory letters are now classified under ceremonial communications. High ranking officials frequently exchange congratulations on special occasions such as national independence days, national holidays, the New Year, occupying a new post, and so on. Therefore, congratulatory letters play a vital role in maintaining and developing friendly mutual relations among nations (Borisova, 2013).

Searle (1976) defines congratulation as a speech act that expresses the speakers' emotions and their feelings towards the listeners. It is an act that is good for the person who has accomplished something, reflecting the satisfaction of speakers. Whenever people congratulate, they reveal their interest in the happiness of others. Marki-Tsilipakon (2001) states that congratulation indicates the pleasure and gratitude of the speaker on a pleasurable occasion.

The act of congratulation can be related to the concept of face and politeness. KerbratOrecchioni (2004, 2005, quoted in Dumitrescu, 2006) argues that congratulation as an expressive speech act is associated explicitly with positive politeness and is a face-saving act because it aims to enhance the positive face of the addressee.

The present study adopts a pragma-stylistic analysis. It emphasizes the illocutionary acts and FSA Politeness Strategies used most frequently by English and Arabic officials and as well as the similarities and differences between them. Furthermore, based on an eclectic model, this study investigates the most prevalent pragma-stylistic devices used in each language in formal congratulatory letters.

\section{Literature Review}

\section{The speech act of congratulations}

Bach and Harnish (1979) define congratulation as expresses gladness for Hs having done or received something good noteworthy (p.51). Another definition by Searle and Vanderveken (1985) shows the situation of fortune as expressing pleasure at the good fortune of others . (p. 212)

People often use this speech act when something positive happens, referring to happy events and impressive actions to express happiness or pleasure to others (Wierzbicka, 1987). Austin (1962) categorizes congratulation as behabitives concerning the verbs of speech acts, expressing a response to the behavior and fortunes of others. On the other hand, Searle (1979) recategorizes it as expressive, as mentioned earlier. Searle (1976) defines the illocutionary point of expressive as "expresses the psychological state specified in the sincerity condition about a state of affairs specified in the propositional content" (p.15). Speakers convey their feelings and attitudes regarding current events, which can be positive (e.g., joy) or negative (e.g., sadness), through propositional content and expressive illocutionary forces. Accordingly, in performing expressive, a speaker does not intend to get the world to fit the words or the words to fit the world (Searle, 
1979). In other words, since the truth of the mentioned proposition is presumed, expressive has no direction to fit in the world. Furthermore, expressive verbs like congratulate, thank, apologize, and so on do not include these phrases; instead, they require gerundive nominalization or another nominal transformation. For example, one says "I congratulate you on winning the race (congratulations on winning the race)" but s/he cannot say "I congratulate you that you won the race" (Searle, 1979, p. 15).

In Arabic, Mubarak literally means blessed, according to the Al-muheet dictionary. The origin of congratulation, Mubarak is blessing from Baraka, meaning accretion and happiness, as stated in the same source. According to the Lisan al Arab and Assihah dictionaries, the verb Mubarak is Yubarik, which means (to ask Allah to bless people or others) such as may Allah bless you. People usually utter this act regarding Allah, who has the power. In Arabic varieties, Mubarak has usually been modified into another lexicon, which is Mabruk, which means both congratulations and blessed. According to Searle and Vanderveken (1985), "to bless is to place the hearer in a state of God's grace by declaring him to be in that state" (p.209). In other words, by blessing, the addressed person wishes good things to happen to the hearer (Wierzbicka, 1987).

Blessing is equivalent to wishing good things for a person. Still, in wishing, his power is purely imaginary: the speaker does not believe that his wish could be self-fulfilling, he merely imagines it ..., while in the case of blessing, the speaker seems to believe that his utterance may indeed have some power. (Wierzbicka, 1987, p. 226)

Leech (1983) reclassifies speech acts depending on the social objective in the principle of politeness, and hence classifies congratulations as a convivial illocutionary function. Congratulations are a positive strategy of politeness that (Brown \& Levinson, 1987) view as a face-threatening act, while (Kerbrat-Orecchioni, 1997) view as a face-enhancing act, depending on the notion of face in the perception of politeness.

\section{The model of politeness of Brown and Levinson (1987)}

Brown and Levinson (1987) developed a more clearly defined model which, although based on a Gricean framework, took into account a deeper approach to social behavior, specifically the notion of the face, which Goffman (1967) influentially introduced into Western social conceptualization as the key to the study of politeness. The entire focus of the theory of Brown and Levinson in practice was on face-threatening acts (FTAs) and the politeness strategies to redress or mitigate them. For example, if someone needs or wants to perform an FTA, they can use a directive speech act to ask someone to lift to the railway station. Brown and Levinson $(1978 ; 1987)$ manipulate the notion of face to refer to essential and universal human expectations as they apply to social interactions. Brown and Levinson ( 1987) affirm that "our notion of face is derived from the English folk term and Goffman, which ties face up with notions of being embarrassed or humiliated, or losing face." (p.61)

The notion of the face includes two basic kinds: the desire not to be imposed on and have freedom of action (negative face) and the desire to be accepted, liked, and understood by others (positive face) (Brown and Levinson, 1987They claim that, although the notion of face is universal, acts that threaten face differ depending on culture. For the negative face, the fundamental claim to territories, personal safeguards, rights to - anti-distraction i.e., with regards 
to freedom of action and freedom from imposition. In contrast, interactants proclaim the positive, consistent self-image or personality (including the desire to value and support this self-image).

Brown and Levinson(1987) use a choice of five main strategies, as shown in Figure1. They order these strategies as bottom-up, which increases the chance of threatening the face. The main threat is using the bald on-record strategy; the most direct, like in Give me a lift to the station.

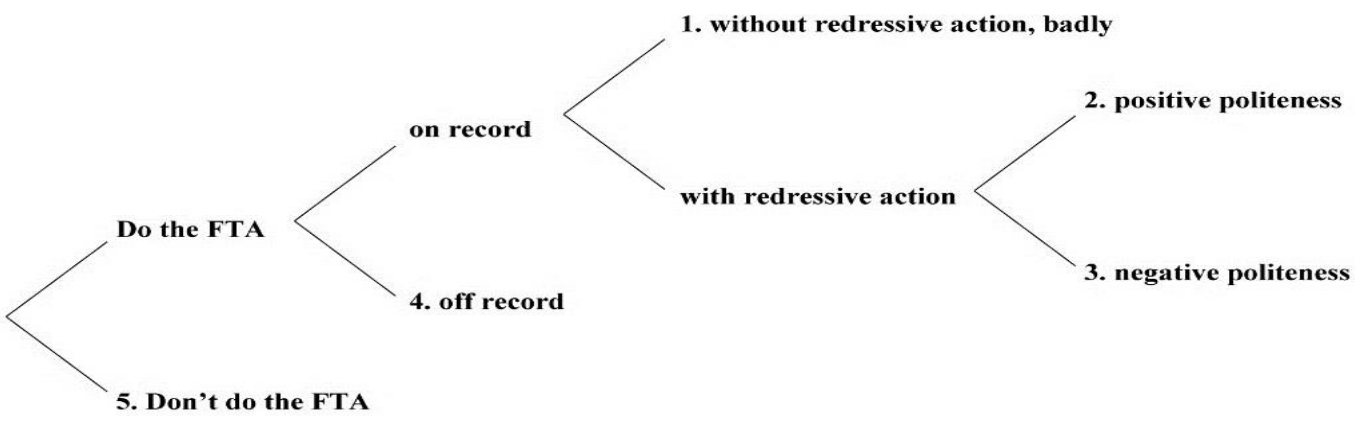

Figure 1: Strategies of Brown and Levinson for avoiding a face-threatening act. Note: Adopted from (Brown \& Levinson,1987, pp. 60,69)

The positive face of the addressee is enhanced by addressing the desire of the hearer to be liked, therefore congratulation is a positive politeness strategy. It also conveys that $\mathrm{X}$ is admirable, attractive, involving the speaker with the hearer claiming common ground. The linguistic realizations of positive politeness strategies are used "as a kind of metaphorical extension of intimacy and as a kind of social accelerator, where $\mathrm{S}$ indicates that he wants to become closer to H" (Brown \& Levinson, 1987, p. 103).

\section{Theoretical Framework}

\section{Pragma-stylistics}

Huang (2012) defines Pragma-stylistics or pragmatic stylistics "refers to applying the findings and methodologies of the theoretical pragmatics to the study of the concept of style in language" (p.19). Stylistics uses formal aspects of language to analyze various texts, especially in narrative and dramatic texts analysis.

Stylistics has progressed to pragmatics seeking explanations for aspects of language usage that stylistics itself cannot provide sufficiently. Modern stylistic studies have shown an interest in pragmatics in addition to examining linguistic utterances. Studies arising from this are called pragma-stylistic studies. Accordingly, Pragma-stylistics aims to provide a context for understanding the relationship between linguistic form and pragmatic perception and how the style of speech differs as the speaker lets the hearer recognize the meaning behind an utterance.

\section{Congratulatory letters}

A letter of congratulation generates affection by touching the ego of the reader. Geffner (2007) states that everyone likes to have accomplishments acknowledged. 
Shelekova et al. (2011) define letters of congratulation as "a type of personal correspondence, usually sent from one person to another." (p. 89)

There are various occasions for congratulatory messages such as promotions, appointments, elections, achievements, awards, honors, weddings, births anniversaries, and retirements. Any letter of congratulations, whether formal or informal, must be sincere and passionate. It may well be short, but personal remarks or references should be included (Borisova,2013).

\section{Ceremonial correspondences}

Gordina et al. (2018) define diplomatic correspondence as "official correspondence between the agents authorized by a state to conduct its foreign relations either at home or abroad, with similarly authorized representative of foreign governments" (p. 117). Diplomatic correspondence is vital in international relations. It has its own set of rules governing etiquette. Some of the distinguishing aspects of diplomatic correspondence include standard vocabulary, grammar, morphology, format, and graphics (Krivorot, 2017).

Diplomatic correspondences include ceremonial communications. Borisova (2013) states:

These may consist of congratulatory messages on the occasion of the election of the head of state, the birth of a royal heir, a royal marriage, the anniversary of a country's independence, or any other national holiday. It may also be an expression of condolence on the death of the head of state or expression of sympathy/regret for his illness, the occurrence of an accident, or any other similar happening. (pp. 7-8)

\section{Methodology}

This study uses a mixed-method approach. Studies of the mixed-method are "studies that are products of the pragmatist paradigm and combine the qualitative and quantitative approaches within different phases of the research process" (Tashakkori \& Teddlie,2008, p. 22). Therefore, a double method, namely a qualitative and quantitative approach, is used in the current study. The qualitative quality criteria get more attention, but high-quality quantitative data should also be collected and analyzed. As a result, the present study aims to identify, explain, and analyze collected data to achieve the best answers to the qualitative research questions. Furthermore, it also aims at collecting and analyzing numerical data using mathematical-based methods.

\section{The Description of Data Collection}

The selected data of this study includes some samples of English and Arabic formal congratulatory letters offered on different formal occasions.

The fact that these letters are from authoritative sources gives credibility to their reliability and validity. Those sources include the Iraqi Ministry of Youth and Sports and the Iraqi Ministry of Foreign Affairs, after going through the proper procedures and approvals, and the rest are from official websites. Moreover, these letters are reliable and valid since they bear the sender's organization signature or seal.

\section{The Procedures:}

The procedures adopted in this study are as follows:

1. Presenting a survey of the terms of the main concepts used in the study.

2. Reviewing the literature related to the pragma-stylistic analysis of congratulatory speech acts. 
3. Adopting an eclectic model based on the updated edition of Brown and Levinson model of politeness (1987), the model of Searle (1969), the model of Nickerson (1999), and the taxonomy of Elwood (2004).

4. Collecting the data for this study and analyzing the selected data in terms of the eclectic model.

5. Discussing the results of the analysis and stating some conclusions and recommendations.

\section{Data Analysis and Discussion \\ Model of Analysis}

This study uses an eclectic model which includes the updated politeness model of Brown and Levinson (1987), the model of Searle (1969), the model of Nickerson (1999), and the taxonomy of Elwood (2004).

English and Arabic officials employed the strategies of Brown and Levinson in detecting and exploring face-saving acts (henceforth FSAs) when offering formal congratulatory correspondences. The current study also uses the taxonomy of Elwood (2004) as a tool for developing a new categorization for writing congratulatory letters. The present study adopts the model of Searle (1969) since it is broad and includes most speech acts verbs. Finally, this study also adopted the model of Nickerson (1999) to analyze the language of politeness in congratulatory letters written by high officials.

A case study of Illocutionary acts and FSA Politeness Strategies in Formal Congratulatory Letters written by English High Officials

Text 1

This text is a congratulatory letter from Mrs. Gabriela Ramos, the Assistant Director-General for Social \& Human Sciences in the UN, to Mr. Adnan Dirjal, the Minister of Youth \& Sports of the Republic of Iraq.

\section{Analysis of the type of Illocutionary Acts in (text1)}

\section{Utterance (1)}

Locution: On behalf of the Director-General I wish to congratulate you on your appointment as Minister of Youth \& Sports of the Republic of Iraq.

Illocutionary act (declarative): the sender declares that she is sending this letter on behalf of her Director-General.

Expressive: the sender congratulates the addressee on his appointment as the new Minister of Youth \& Sports of the Republic of Iraq.

\section{Utterance (2)}

Locution: I am convinced that your personal engagement and previous experience as a football player and team coach will serve you well and contribute to strengthening sport and the development of youth in your country.

Illocutionary act (assertive (representative): the sender confirms that the promising good career of the addressee will serve him well in his new position and contribute to developing youth \& sports fields in his country. 


\section{Utterance (3)}

Locution: Under the UNESCO Operational Strategy On Youth (2014-2021), we look forward to cooperating with you to ensure that young people in Iraq are engaged in policies and programs that affect them and that they lead actions to promote peace and sustainable development.

Illocutionary act (commissive): the sender commits herself to a future responsibility towards the addressee.

\section{Utterance (4)}

Locution: We also stand ready to assist Iraq in supporting youth's social innovation as an important contribution to the achievement of the 2030 Agenda, the National Reconstruction and Development Plan of the Iraqi Government, Iraq Recovery and Resilience program and the" Revive the Spirit of Mosul" initiative. In this regard, the UNESCO National Office in Baghdad will be very pleased to liaise with your cabinet.

Illocutionary act (commissive): the sender continues her confirmation of a future responsibility towards the addressee.

Expressive: the sender expressed the pleasure of the UNESCO to liaise with the cabinet of the addressee.

\section{Utterance (5)}

Locution: Iraq's commitment to the promotion and protection of sport values and integrity is illustrated by its actions as a State Party to the International Convention against Doping in Sport, notably its participation in the Working Group (2018-2019) on the development of Operational Guidelines and a Framework of Consequences for non-compliance with the Convention.

Illocutionary act (assertive (representative): the sender confirms that the country of the addressee commitment to the promotion and protection of sport values and integrity which is clearly shown in its substantial participation in the Working Group (2018-2019) as a State Party to the International Convention against Doping in Sport.

\section{Utterance (6)}

Locution: In view of MINEPS VII (Nairobi, 2021) and of the eighth session of the Conference of Parties to the Anti-Doping Convention (UNESCO Headquarters,2021), we hope that Iraq will play an important role in the implementation of the Convection and the Kazan Action Plan in the region.

Illocutionary act (expressive): the sender expresses her hope that the country of addressee will play an essential role in the coming action in Kazan.

\section{Utterance (7)}

Locution: We look forward to deepening our collaboration and to working towards the implementation of the 2030 Agenda.

Illocutionary act (commissive): the sender commits herself to a future responsibility towards the addressee.

\section{Utterance (8)}

Locution: I am confident that, Together, we can help ensure that youth development, sport, and 
Arab World English Journal (AWEJ) Volume 12. Number 3. September 2021

A Pragma- Stylistic Analysis of Formal Congratulatory Letters

Al-Janabi \& Al-Tememi

physical education are recognized and supported as essential catalysts for peace and sustainable development.

\section{Illocutionary act:}

Assertive: The sender emphasizes her willingness to collaborate with the addressee to promote youth and sports development.

Table No.1 below illustrates the frequency and percentage distribution of types of illocutionary acts in (text1).

Table.1 Frequency and percentage distribution of types of illocutionary acts in (Text 1)

\begin{tabular}{|c|c|c|}
\hline Illocutionary Speech Acts & Frequencies & Percentages \\
\hline Declarative & 1 & $10 \%$ \\
\hline Expressives & 3 & $30 \%$ \\
\hline Assertives & 3 & $30 \%$ \\
\hline Commissives & 3 & $30 \%$ \\
\hline Total No of Acts & 10 & $100 \%$ \\
\hline
\end{tabular}

The sender in (text1) above uses four of the categories of illocutionary acts proposed by Searle (1969). Except for declarative, which appeared only once in utterance (No.1), the sender distributed that speech acts equally. Expressives appear in utterances (No.1, 4, and 6), while assertive appears in utterances ( No.2, 5, and 8). Finally, commissives appear in three utterances (No.3. 4, and 7).

The sender uses this style to show her responsibility towards the addressee and her support towards him in ensuring that young people in his country are engaged in policies and programs that affect them and lead actions to promote peace and sustainable development.

\section{Analysis of the type of the FSA Politeness Strategies used in (text 1)}

The current letter is a congratulatory letter dated July 1, 2020, from Mrs. Gabriela Ramos, the Assistant Director-General for Social \& Human Sciences in the UN, to Mr. Adnan Dirjal, the newly appointed Iraqi Minister of Youth \& Sports.

The sender starts her letter with the salutation Dear Minister, which implies a conventional polite behavior toward the addressee by addressing him with his title job rather than his bare name. This pattern indicates that the sender employs the Negative Politeness Strategy of Brown and Levinson (Give deference) to avoid violating the negative face of the addressee by claiming a deep intimacy with him, implying that the sender is attempting to maintain and consider the social distance with the addressee. Furthermore, the same act implies employing the Positive Politeness Strategy of Nickerson (Use of Appropriate Forms of Pattern), which entails establishing a friendly and harmonious relationship with the addressee. This pattern is the most conventional form of expression; i.e., it is a projected and expected action performed by the sender, therefore considered an FSA positive politeness strategy.

In utterance (No.1), the sender employs the congratulatory strategy of Elwood (Illocutionary Force Indicating Device (IFID)) by uttering the word congratulate. The sender extends her congratulations towards the addressee on his appointment as the Minister of Youth and Sports of the Republic of Iraq. 
In utterance (No.2), the sender employs the Positive Politeness Strategy of Brown \& Levinson (Be optimistic) in addition to the politeness strategy of Elwood (Encouragement) to convey her optimism towards the addressee and her confidence in his promising career and experience, which will serve him well in his new post.

The sender in utterance (No.3) employs two of the Positive Politeness Strategies Brown \& Levinson: (Be optimistic) and (Notice, attend to $\mathrm{H}$ interests). With this pattern, the sender expresses her optimism towards cooperating with the addressee and making him feel good about themselves and their interests.

In utterance (No.4), the sender employs the Positive Politeness Strategy of Brown \& Levinson (Assert or presuppose S's knowledge of and concern for H's wants) through showing her readiness to assist the government of the addressee in supporting the social innovation of youth by involving them in a variety of youth development programs. In addition, the sender employs the politeness strategy of Elwood (Expressions of happiness), in the same utterance, by stating that the UNESCO National Office in Baghdad will be pleased to liaise with your cabinet. The sender employs this strategy to support the positive face of the addressee and make them feel good about their interests.

The sender in utterance (No5) employs the politeness sub-strategy of Elwood (Statements assessing the situation as positively) by evaluating the activities of the country of the addressee as positive, which is evident in its performance as a good participant.

In utterance (No.6), the sender uses two of the positive politeness strategies of Brown \& Levinson: (Be optimistic) and (Notice, attend to $\mathrm{H}$ interests), showing her concern about the interests of the addressee and hoping that his country will play an essential role in the implementation of the Anti-Doping Convention and the forthcoming Kazan Action Plan in the region.

Utterance (No.7) is pre-close to the letter. This utterance expresses the optimism and confidence of the sender in the good mutual interest of both parties by expressing his desire to strengthen their collaboration and work towards the implementation of the forthcoming 2030 Agenda. As a result, this indicates that the sender employs the positive politeness strategy of Brown \& Levinson (Be optimistic).

In utterance (No.8), the sender uses two of the positive politeness strategies of Brown \& Levinson: (Be optimistic) and (Include both $\mathrm{S}$ and $\mathrm{H}$ inactivity) to express his hope and faith that both parties can achieve their shared interests. By using this pattern, the sender wants to attend to the desires of the addressee, and the latter expects their willingness to participate and join others in the uttered action.

At the end of the letter, the sender closes it as usual with the closing expression Yours sincerely and his signature by employing the positive politeness strategy of Nickerson (Use of appropriate forms of address). 
Arab World English Journal (AWEJ) Volume 12. Number 3. September 2021

A Pragma- Stylistic Analysis of Formal Congratulatory Letters

Al-Janabi \& Al-Tememi

\section{Text 2}

This text is a congratulatory letter from Mr. Donald J. Trump, President of the USA, to Mr. Barham Salih, President of the Republic of Iraq.

\section{Analysis of the type of Illocutionary Acts in (text2)}

\section{Utterance (1)}

Locution: On behalf of the American people, I wish you and the people of Iraq a happy Nowruz. Illocutionary Act (declarative): The sender expresses his wish to send this congratulatory letter on behalf of his people.

Expressive: The sender, on behalf of himself and his people, wishes the addressee and his people a happy Nowruz holiday.

\section{Utterance (2)}

Locution: This is a special holiday of peace and renewal for all.

Illocutionary Act (assertive): the sender affirming that this is a memorable holiday of peace and renewal for all.

\section{Utterance (3)}

Locution: This year the holiday has even greater significance, as our countries work to bring peace and stability to Iraq.

Illocutionary Act (assertive (representative)): the sender commits himself to the truthfulness of the proposition of the situation by asserting that this holiday has even greater significance because his government works to bring peace and stability to the country of the addressee.

\section{Utterance (4)}

Locution: We have made great progress together against ISIS, and I look forward to new opportunities to build our economic and security relations with your government.

Illocutionary Act (assertive): the sender affirms the significant progress done together against ISIS.

Commissive: the sender commits himself to a future responsibility with the addressee through looking forward to new opportunities to work with him and his government.

Table. 2 Frequency and percentage distribution of types of illocutionary acts in (Text 2)

\begin{tabular}{|c|c|c|}
\hline Illocutionary Speech Acts & Frequencies & Percentages \\
\hline Declarative & 1 & $16.7 \%$ \\
\hline Expressives & 1 & $16.7 \%$ \\
\hline Assertive & 3 & $50 \%$ \\
\hline Commissives & 1 & $16.7 \%$ \\
\hline Total No of Acts & 6 & $100 \%$ \\
\hline
\end{tabular}

The sender uses five of the illocutionary acts of Searle (1969), as stated in table No. (2) above. Expressives appear in one utterance only (No.1) in a total rate of (16.7\%), and declarative appears in the same utterance ( No.1) in a total rate of (16.7\%). Assertive appears in three utterances (No.2,3, and 4 ) in a total rate of $(50 \%)$. Finally, commissives appear in one utterance only (No.4) in a total rate of (16.7\%). 
The sender's style is remarkable in (text 2) for distributing speech acts in the same portions except for assertive, which occurred three times in this text. In this style of use, the sender attempts to seize this opportunity to assert his support towards the addressee and his government and express his positive intention to consolidate bilateral ties between the two parties.

\section{Analysis of the type of the FSA Politeness Strategies used in (text 2)}

This text is a congratulatory letter dated December 21, 2020, from Mr. Donald J. Trump, President of the United States, to Mr. Barham Salih, President of the Republic of Iraq, on the occasion of the Nowruz holiday.

The sender starts his letter with the salutary expression Dear Mr. President, which is a conventional behavior to address president to president in diplomatic correspondences. This pattern implies the employment of the Positive politeness Strategy of Nickerson (Use appropriate forms of address), where this strategy marked the desire of the sender to preserve a friendly and solid relationship with the addressee.

In utterance (No.1), the sender conveys his positive intention towards the addressee and his people, wishing them a pleasant Nowruz holiday in an attempt to build bilateral ties between the two parties employing Brown and Levinson's Positive Politeness Strategy (Notice, attend to $\mathrm{H}$ interests). In this utterance, the sender also uses the politeness strategy of Elwood (Offer of good wishes) to convey his good wishes towards the addressee on this happy occasion.

In utterances (No.2 \&3), the sender intensifies his interest towards the addressee by expressing this occasion as a special one for peace and renewing the strong bilateral ties between the two parties and also showing its greater significance as his country works to bring peace and stability to the government of the addressee. Therefore, this pattern realizes the employment of the Positive Politeness Strategy of Brown \& Levinson (intensify interest to H).

In utterance (No.4), the sender employs the Positive Politeness Strategy of Brown \& Levinson (Include both $\mathrm{S}$ and $\mathrm{H}$ in the activity), which is pre-close to this letter. The sender, by using the $1^{\text {st }}$ person inclusive pronoun $W e$ and the word together includes both parties in the action uttered. Furthermore, the sender also employs the Positive Politeness Strategy of Brown \& Levinson (Presuppose/raise/assert common ground). The sender, by using the expression I look forward conveys his positive intention in establishing common grounds with the government of the addressee to build economic and security relations.

Finally, the sender closes his letter using the expression sincerely and his signature. This writing style reveals a conventional and formal style predicted and expected in such contexts. With this pattern, the sender employs the Positive Politeness Strategy of Nickerson (Use appropriate forms of address).

Table No.2 illustrates the most frequent FSA Politeness Strategies in English texts. 
Arab World English Journal (AWEJ) Volume 12. Number 3. September 2021

A Pragma- Stylistic Analysis of Formal Congratulatory Letters

Al-Janabi \& Al-Tememi

Table No.3 The Overall Number and Percentage of the FSA Politeness Strategies in English Texts.

\begin{tabular}{|c|c|c|c|c|}
\hline Name of strategy & Models & $\begin{array}{c}\text { Kind of } \\
\text { strategy }\end{array}$ & No. & Percentage \\
\hline $\begin{array}{c}\text { Give deference } \\
\text { Use appropriate forms of } \\
\text { address }\end{array}$ & $\begin{array}{c}\text { Brown \& } \\
\text { Levinson }\end{array}$ & Neg. & 1 & $3.8 \%$ \\
\hline $\begin{array}{c}\text { Illocutionary Force } \\
\text { Indicating Device (IFID) }\end{array}$ & Elwood & Ptrategy & 1 & $23.1 \%$ \\
\hline $\begin{array}{c}\text { Be optimistic } \\
\text { Encouragement }\end{array}$ & $\begin{array}{c}\text { Brown \& } \\
\text { Levinson }\end{array}$ & Pos. & 5 & $19.2 \%$ \\
\hline $\begin{array}{c}\text { Elwood } \\
\text { Notice, attend to H interests }\end{array}$ & $\begin{array}{c}\text { Brown \& } \\
\text { Levinson }\end{array}$ & Strategy & 1 & $3.8 \%$ \\
\hline $\begin{array}{c}\text { Presuppose, raise, assert } \\
\text { common grounds }\end{array}$ & $\begin{array}{c}\text { Brown \& } \\
\text { Levinson }\end{array}$ & Pos. & 2 & $11.5 \%$ \\
\hline Expressions of happiness & Elwood & Strategy & 1 & $7.7 \%$ \\
\hline $\begin{array}{c}\text { Statements assessing the } \\
\text { situation as positively }\end{array}$ & Elwood & Sub-strategy & 1 & $3.8 \%$ \\
\hline $\begin{array}{c}\text { Include both S \& H in the } \\
\text { activity }\end{array}$ & $\begin{array}{l}\text { Brown \& } \\
\text { Levinson }\end{array}$ & Pos. & 2 & $3.8 \%$ \\
\hline Offer of good wishes & Elwood & Strategy & 1 & $7.7 \%$ \\
\hline $\begin{array}{c}\text { Intensify interest to H } \\
\text { Levinson }\end{array}$ & Pos. & 2 & $\mathbf{1 0 0} \%$ \\
\hline
\end{tabular}

\section{A case study of Illocutionary acts and FSA Politeness Strategies in Formal Congratulatory Letters written by Arabic High Officials}

Text 3

This text is a congratulatory letter from Mr. Muhammad Ali Al-Hakim, Minister of Foreign Affairs of the Republic of Iraq, to Sheikh Khalid bin Ahmed Al Khalifa, Minister of Foreign Affairs of Bahrain.

Analysis of the type of Illocutionary Acts in (text3)

\section{Utterance (1)}

Locution: بمناسبة حلول عيد الاضحى المبارك، يسرني ان اتقدم لمعاليكم بأطيب التهاني و اصدق التمنيات Trans.(On the occasion of the blessed Eid al-Adha, I am pleased to extend to you my best congratulations and sincere wishes).

Illocutionary Act (expressive): (congratulating and wishing) the sender expresses his pleasure to extend his congratulations and good wishes towards the addressee on the occasion of the blessed Eid alAdha to stress and reinforce the social bonds between the two parties.

Utterance (2)

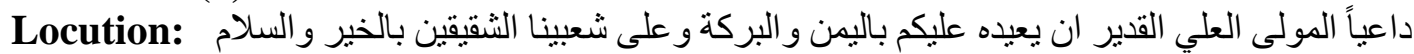

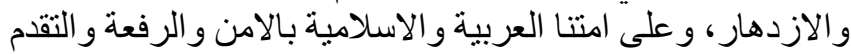


Trans. (I pray to the Almighty Allah to return this occasion to you in prosperity and blessing and to our two brotherly people with goodness, peace, and wealth, and to our Arab and Islamic nation with security, elevation, and progress).

Illocutionary Act (expressive): (a wish or a ritual formula) The sender prays to the Almighty Allah to return this happy occasion to the addressee and their two brotherly people, as well as the Arab and Islamic nation, with prosperity, blessing, security, elevation, and progress, in order to maintain the solidarity and good relations between the two parties.

\section{Utterance (3)}

\section{Locution: $\quad$ وكل عام و انتم بخير}

Trans. (May every year find you in good health).

Illocutionary Act (expressive): the sender prays to the Almighty Allah to find the addressee in good health in many happy returns.

Table.4 Frequency and percentage distribution of types of illocutionary acts in (Text 3)

\begin{tabular}{|c|c|c|}
\hline Illocutionary Speech Acts & Frequencies & Percentages \\
\hline Expressives & 3 & $100 \%$ \\
\hline Total No of Acts & 3 & $100 \%$ \\
\hline
\end{tabular}

The sender's style is entirely expressive in (text3) to convey his congratulations and good wishes towards the addressee on the occasion of the blessed Eid Al-Adha. This pattern reflects the great gratitude of the sender and his consideration towards the addressee, which maintains solidarity and reinforces the social bonds between the two parties.

\section{Analysis of the type of the FSA Politeness Strategies used in (text 3)}

This text is a congratulatory letter dated August 2019 from Mr. Muhammad Ali Al-Hakim, Minister of Foreign Affairs of the Republic of Iraq, to Sheikh Khalid bin Ahmed Al Khalifa, the Minister of Foreign Affairs of Bahrain, on the occasion of the blessed Eid Al-Adha.

سمو الثيخ خالد بن محمد آل خليفة المحترم، The sender starts this letter with the salutary expression وزئل وزير خارجية مملكة البحرين ،السلام عليكم ورحمة الله وبركاته Ahmed Al Khalifa, the Minister of Foreign Affairs of the Kingdom of Bahrain, May peace, mercy and blessings of God be upon you) where the expression سمو الثيخ, which means (His Highness the honorable Sheikh) precedes the name of the minister of Foreign Affairs of Bahrain. This writing style is a conventional way used to address Arab royal personalities to manifest courtesy and consideration. With this pattern, the sender attempts to avoid damaging the negative face of the addressee by claiming a fairly deep intimacy. Therefore, this act implies preserving the degree of social distance with the addressee. Hence, the sender uses the FSA Negative Politeness Strategy of Brown \& Levinson (Give deference) in this respect. Furthermore, the same utterance realizes the employment of the Positive Politeness Strategy of Nickerson (Use of appropriate forms of address) to denote the interest of maintaining interpersonal and harmonized relations with the addressee. This act is a conventional writing style used in formal letters, where this type of writing is predicted and expected to reflect the politeness behavior of the sender towards the addressee. 
In utterance (No.1), the sender performs three of the politeness strategies Elwood; the first one is the sub-strategy (Expressions of personal happiness) by using the word يسرني, which means (I am pleased), the second one is (Illocutionary Force Indicating Device (IFID)) by using the expression التهاني, which means (congratulations) and the third strategy is (Offer of good wishes) by uttering the expression واصدق التمنيات, which means (sincere wishes). The sender uses another strategy in this utterance, which is the Positive Politeness Strategy of Brown \& Levinson (Exaggerate (interest, sympathy with $\mathrm{H}$ )) by using the words أطيب, which means (the best) and أصدق which means (sincerest). This pattern conveys an extreme degree of politeness from the side of the sender towards the addressee to stress and reinforce the strong relations between the two parties.

In utterance (No.2), which is pre-close to this letter, the sender also uses the congratulatory strategy of Elwood (Offer of good wishes) by extending his supplication to the Almighty Allah to return this happy occasion to the addressee and their two brotherly people with prosperity, blessing, goodness, peace, security, elevation, and progress in addition to the Positive Politeness Strategy of Brown \& Levinson (Use in-group identity markers) by using the expressions شعبينا الثقيقين, which means (to our two brotherly people) and امتنا العربية والاسلامية, which means (our Arab and Islamic nation) to stress their national belonging to the Arab homeland and the Islamic nation.

The sender ends his letter with the utterance (No.3), which reflects the employment of the congratulatory strategy of Elwood (Offer of Good wishes) by offering the addressee his good wishes in a step to maintain their solidarity and good relations. This statement is considered a conventional formal behavior predicted and expected in such Arab ritual occasions.

Finally, the sender closes his letter with his signature by employing the Positive Politeness Strategy of Nickerson (Use of appropriate forms of address).

\section{Text 4}

This text is a congratulatory letter from Mr. Othman Ali Farhood Al-Ghanmi to Mr. Louis Raphael I Saco, the Honorable Patriarch of the Chaldeans in Iraq and the world. Analysis of the type of Illocutionary Acts in (text4)

\section{Utterance (1)}

Locution: بمناسبة قرب حلول أعياد الميلاد المجيد نتقدم بأزكى التهاني و التبريكات

Trans. (On the occasion of the advent of the glorious Christmas, we extend our sincere congratulations and blessing).

Illocutionary Act (expressive): (congratulating) the sender extends his sincere congratulations and blessing towards the addressee on the occasion of the advent of the glorious Christmas.

\section{Utterance (2)}

Locution: سائلين المولى - جل في علاه- ان يعيد هذه المناسبة على بلدنا العزيز باليمن والخير والبركات Trans. (asking the Lord Almighty to return this occasion to our dear country with goodness, prosperity, and blessings).

Illocutionary Act (expressive): (good wishes) the sender prays to Almighty God to return this occasion to the addressee and his dear country with goodness, prosperity, and blessings. 
Utterance (3)

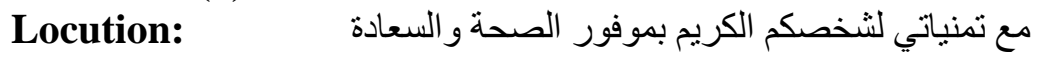

Trans. (with my best wishes to your honorable person of good health and happiness).

Illocutionary Act (expressive): (good wishes) the sender expresses his good wishes towards the addressee.

Table.5 Frequency and percentage distribution of types of illocutionary acts in (Text 4)

\begin{tabular}{|c|c|c|}
\hline Illocutionary Speech Acts & Frequencies & Percentages \\
\hline Expressives & 3 & $100 \%$ \\
\hline Total No of Acts & 3 & $100 \%$ \\
\hline
\end{tabular}

As shown in table (5) above, the sender's style is entirely expressive in this text to express his sincere congratulations and good wishes to the addressee on the occasion of the advent of the glorious Christmas.

\section{Analysis of the type of the FSA Politeness Strategies used in (text 4)}

This text is a congratulatory letter dated January 6, 2016, from Mr. Othman Ali Farhood AlGhanmi, Staff General, to His Beatitude Mr. Louis Raphael I Saco, the Honorable Patriarch of the Chaldeans in Iraq and the world, on the occasion of the advent of the glorious Christmas.

السيب لويس روفائيل الاول ساكو The sender, in the current letter, starts with the salutary expression which means (The honorable Mr. Louis Raphael I Saco, the Honorable Patriarch of the Chaldeans in Iraq and the world). The sender by using the syntactic expression السيد which means (Mr.) and intentionally mentioning the job title of the addressee in front of his name reflects the employment of the Positive Politeness Strategy of Nickerson (Use of appropriate forms of address). This writing style is a conventional formal politeness behavior predicted and expected in such a situation. Furthermore, the sender uses the word المحترم which means (honorable) to exhibit a formal way of addressing high officials and support the positive face of the addressee, reflecting the employment of the FSA Positive Politeness Strategy of Brown \& Levinson (Give gifts to $\mathrm{H}$ ) to express an honorific and respectful attitude towards the addressee, implying that the latter is not their equal, and hence has a greater social power, where this syntactic behavior reflects the manipulation of the FSA Negative Politeness Strategy of Brown \& Levinson (Give deference). In this respect, the sender performed a double act towards the positive and negative face of the addressee.

In utterance (No.1), the sender employs the congratulatory strategy of Elwood (Illocutionary Force Indicating Device (IFID)), by using the word التهاني which means (congratulations), as well as the Positive Politeness Strategy of Brown \& Levisohn (Exaggerate (interest, sympathy with the $\mathrm{H}$ )), conveying his exaggerated interest and sympathy towards the addressee by using the expression بأزكى التهاني والتبريكات which means (our sincere congratulations and blessing). This pattern implies using (Hyperbole) as a writing style to show his over respect and interest towards the addressee. It seems that the function of this style is to strengthen the spirit of brotherhood and partnership between the people of one nation.

In utterance (No.2), which is pre-close to the letter, the sender employs the congratulatory strategy of Elwood (Offer of good wishes) by praying to the Almighty Allah to return this 
occasion to his country with goodness, prosperity, and blessings. Furthermore, this utterance realizes the employment of the Positive Politeness Strategy of Brown \& Levisohn (Use in-groupidentity) by using the expression بلدنا العزيز which means (our dear country) to stress his pride in belonging to this country.

In the last utterance (No3), the sender employs the congratulatory strategy of Elwood (Offer of good wishes). Moreover, by utilizing the FSA Positive Politeness Strategy of Brown and Levinson(Give gifts to $\mathrm{H}$ ), the sender tries to support the positive face addressee by using the most formal, respectful, and deferential expression لشخصكم الكريم which means (your honorable person), reflecting the aim of the sender to convey an honorific and respectful attitude towards the addressee, implying that the latter is not their equal, and hence of greater social power. Accordingly, this stylistic behavior reflects the manipulation of the FSA Negative Politeness Strategy of Brown \& Levinson (Give deference). Furthermore, this utterance realizes the employment of the FSA Positive Politeness Strategy of Brown \& Levinson (Exaggerate (interest, sympathy with the H)) by using the exaggerating expression بموفور الصحة والسعادة which means (good health and happiness) to convey the over interest and courtesy of the sender towards the addressee.

The sender closes his letter with his signature employing the Positive Politeness Strategy of Nickerson (Use of appropriate forms of address).

Table No.6 The Overall Number and Percentage of the FSA Politeness Strategies in Arabic texts.

\begin{tabular}{|c|c|c|c|c|}
\hline Name of strategy & Models & Kind of strategy & No. & Percentage \\
\hline $\begin{array}{c}\text { Use appropriate forms of } \\
\text { address }\end{array}$ & Nickerson & Pos. & 4 & $19.0 \%$ \\
\hline Give gifts to H & Brown \& Levinson & Pos. & 2 & $9.5 \%$ \\
\hline Give deference & Brown \& Levinson & Neg. & 3 & $14.3 \%$ \\
\hline $\begin{array}{c}\text { Illocutionary Force Indicating } \\
\text { Device (IFID) }\end{array}$ & Elwood & Strategy & 2 & $9.5 \%$ \\
\hline $\begin{array}{c}\text { Exaggerate (interest, } \\
\text { sympathy) }\end{array}$ & Brown \& Levinson & Pos. & 3 & $14.3 \%$ \\
\hline $\begin{array}{c}\text { Offer of good wishes } \\
\text { Use -in-group identity markers }\end{array}$ & Brown \& Levinson & Strategy & 5 & $23.8 \%$ \\
\hline \multicolumn{2}{|r|}{} & Pos. & 2 & $9.5 \%$ \\
\hline
\end{tabular}

\section{Conclusion}

The following are the significant conclusions arrived at from Illocutionary Acts and FSA Politeness Strategies used by English and Arabic officials:

1. The quantitative-qualitative analysis reveals that assertive seems to have the highest frequency of occurrences and percentages of illocutionary acts performed by English 
high officials in the selected English formal congratulatory letters. At the same time, expressive was more prevalent in Arabic data..

2. The analysis also reveals that the FSA strategy (Use appropriate forms of address) constitutes the majority of the overall frequency of occurrences in both English and Arabic data, particularly in the salutary, pre-close, and signature parts, still appears more frequently in English data. Furthermore, (Exaggerate interest, sympathy with H) comes next in the Arabic data, while (Be optimistic) occurs more in English data.

3. Other strategies (politeness strategies and sub-strategies of Elwood) come next in the overall frequency of occurrences and percentages of politeness strategies. (Offer of good wishes, IFID, and Expressions of personal happiness) constitute most of the overall frequency of occurrences of both English Arabic data, but they occur more in Arabic data. The high Arabic officials are religiously inclined. The majority of their wishes are prayers/blessings, whereas English high officials do not use religious expressions in their congratulatory letters.

4. The data analysis results reveal the presence of the FSA Negative Politeness Strategies, which are uncommon in formal congratulatory letters. Both English and Arabic officials use the FSA Negative Politeness Strategies. Still, they constitute a higher portion of occurrence in the Arabic data, which implies that both English and Arabic officials prefer to use the FSA Negative Politeness Strategies (Give deference $\&$ Be conventionally indirect) in their congratulatory formal correspondences to reflect the formal and humble style of their writings while not infringing on the negative faces of their addressees and maintaining the social distance with them.

5. Finally, the analysis reveals that high Arabic officials use exaggeration (hyperbole) as a stylistic device in their formal congratulatory letters, as evidenced by the use of the FSA Positive Politeness Strategy (Exaggerate interest, sympathy with $\mathrm{H}$ ) since high Arabic officials are prone to glorifying people in positions of authority. In contrast, English high officials tend to be more moderate.

\begin{abstract}
About the Authors:
Muna Y. Al-Janabi received her B.A. degree in English Language from the University of Baghdad/College of Languages/ Department of English in 1999. She is currently an MA student at the same university and college. Her research interests include Pragma-Stylistics, General Linguistics. https://orcid.org/0000-0002-0475-995X
\end{abstract}

Ibtihal M. Al-Tameemi, PhD in Linguistics and Translation and is an Assistant Professor at the department of English /College of Languages /University of Baghdad. She is a member of Iraqi Translators Association (ITA) since 1992 and APETAU. Her scopes of interest include Translation and interpreting, literary translation, applied linguistics and ELT. https://orcid.org/0000-0002-2182-3159.

\title{
References
}

Austin, J.L. (1962). How to Do Things with Words. 2nd ed. Oxford: Oxford University Press. Bach, K., \& Harnish, R. M. (1979). Linguistic Communication and Speech Acts. Cambridge: MIT Press. 
Arab World English Journal (AWEJ) Volume 12. Number 3. September 2021

A Pragma- Stylistic Analysis of Formal Congratulatory Letters

Al-Janabi \& Al-Tememi

Borisova, Y., V.(2013). Diplomatic Correspondence. The University Of World Economy And Diplomacy. UWED Mustaqillik avenue, Tashkent, Republic of Uzbekistan.

Brown, P., \& Levinson, S. (1978). Universals in Language Usage: Politeness Phenomena. In E. Goody (Ed.), Questions and Politeness: Strategies in Social Interaction (pp. 56-310). Cambridge: Cambridge University Press.

Brown, P., \& Levinson, S. (1987). Politeness: Some language Universals in Language Use. Cambridge: Cambridge University Press.

Dumitrescu, D. (2006). Noroc!; Merci;! que lindo!; sorry: some polite speech acts across cultures. Southwest Journal of Linguistics, 25(2), 1-38. [Retrieved July 21, 2020, from https://go.gale.com/ps/advancedSearch.do?method=doSearch\&searchType=AdvancedSe archForm\&userGroupName=anon\%7E496e281c\&inputFieldNames[0]=AU\&prodId=AO NE\&inputFieldValues[0]=\%22Domnita+Dumitrescu\%22

Elwood, K. (2004). Congratulations!: A Cross-Cultural Analysis of Responses to Another's Happy News. 文化論集, (25), 355-386. [Retrieved October 8, 2020, from https://ci.nii.ac.jp/naid/120000792044/

Geffner, A. (2007). How to Write Business Letters. New York, Barron's Educational Series, Inc. Goffman, E.(1967). Interaction Ritual: Essays in face-to-face behavior. New York: Doubleday. Gordina E.A. \& Afanasieva L.S. (2018). Business and Diplomatic Correspondence (S. Akram, Trans.). Novosibirsk: Novosibirsk University of Management and Economics. Retrieved October 11, 2020, from: https://z-lib.org/

Huang, Y. (2012). Pragmatics. Oxford: Oxford University Press.

January 5, 2021. A congratulatory letter sample. Retrieved from:

https://presidency.iq/EN/Details.aspx?id=1849

Kerbrat-Orecchioni, C. (1997). A multilevel approach in the study of talk-in-interaction. Pragmatics, 7, 1-20.

Kerbrat-Orecchioni, C. (2004). Introducing Polylogue. Journal of Pragmatics, 36 (1), 1-24.

Kerbrat-Orecchioni, C. (2005). Politeness in France: How to buy bread politely (pp. 29-44). Multilingual Matters.

Krivorot, V. V. (2017). Diplomatic Language As One of the Most Effective Ways of Intercultural Communication. Retrieved October 15, 2020, from:

https://elib.bsu.by/bitstream/123456789/186536/1/DIPLOMATIC\%20LANGUAGE\%20A S\%20ONE\%20OF\%20THE\%20MOST\%20EFFECTIVE\%20WAYS\%20OF\%20INTERC ULTURAL\%20COMMUNICATION.pdf

Leech, G.(1983). Principles of Pragmatics. London: Longman.

Makri-Tsilipakon, M.(2001). Congratulation and bravo! In A. Bayraktaroglu \& M. Sifianou (Eds.), Linguistic Politeness Across Boundaries: The case of Greek and Turkish, pp.137176.

Nickerson, C. (1999). The use of politeness strategies in business letters. In R. Geluykens \& K. Pelsemakers (Eds.), Discourse in Professional Contexts (pp.127-142). Munchen: Lincom.

November 2, 2020. A congratulatory letter sample. Retrieved from:

http://saint-adday.com/?p=15567

Searle, J. (1969). Speech Acts. Cambridge: Cambridge University Press.

Searle, J. (1976). Classification of Illocutionary Acts. Language and Society, 5, 1-23.

Searle, J. (1979). Expressions and Meaning: Studies in the Theory of Speech Acts. Cambridge: Cambridge University Press. 
Arab World English Journal (AWEJ) Volume 12. Number 3. September 2021

A Pragma- Stylistic Analysis of Formal Congratulatory Letters

Al-Janabi \& Al-Tememi

Searle, J. R., \& Vanderveken, D. (1985). Foundations of Illocutionary Logic. Cambridge; NY: Cambridge University Press.

Shelekova, I.V., Nikulshina, N.L., Makeeva, M.N., Genina, N.A., \& Glivenkova, O.A. (2011). How to conduct Business Correspondence in English (S. Akram, Trans.). Tambov State Technical University - ISBN 978-5-8265-0976-0. Retrieved October 16, 2020, from: http://window.edu.ru/resource/548/76548/files/makeeva1.pdf

Tashakkori, A., \& Teddlie, C. (2008). Introduction to mixed - method and mixed model studies in social and behavioral science. In V.L. Plano-Clark \& J. W. Creswell (Eds.), The mixed-methods reader, (pp. 7-26).

Wierzbicka, A. (1987). English Speech Act Verbs: A Semantic Dictionary. Orlando, FL: Academic Press.

\section{Appendix A}

Text (1): a congratulatory letter written by an English high official

Sender: Mrs. Gabriela Ramos, the Assistant Director-General for Social \& Human Sciences in the UN

Addressee: Mr. Adnan Dirjal, the Iraqi Minister of Youth \& Sports

Date: July 1, 2020

Occasion: New appointment

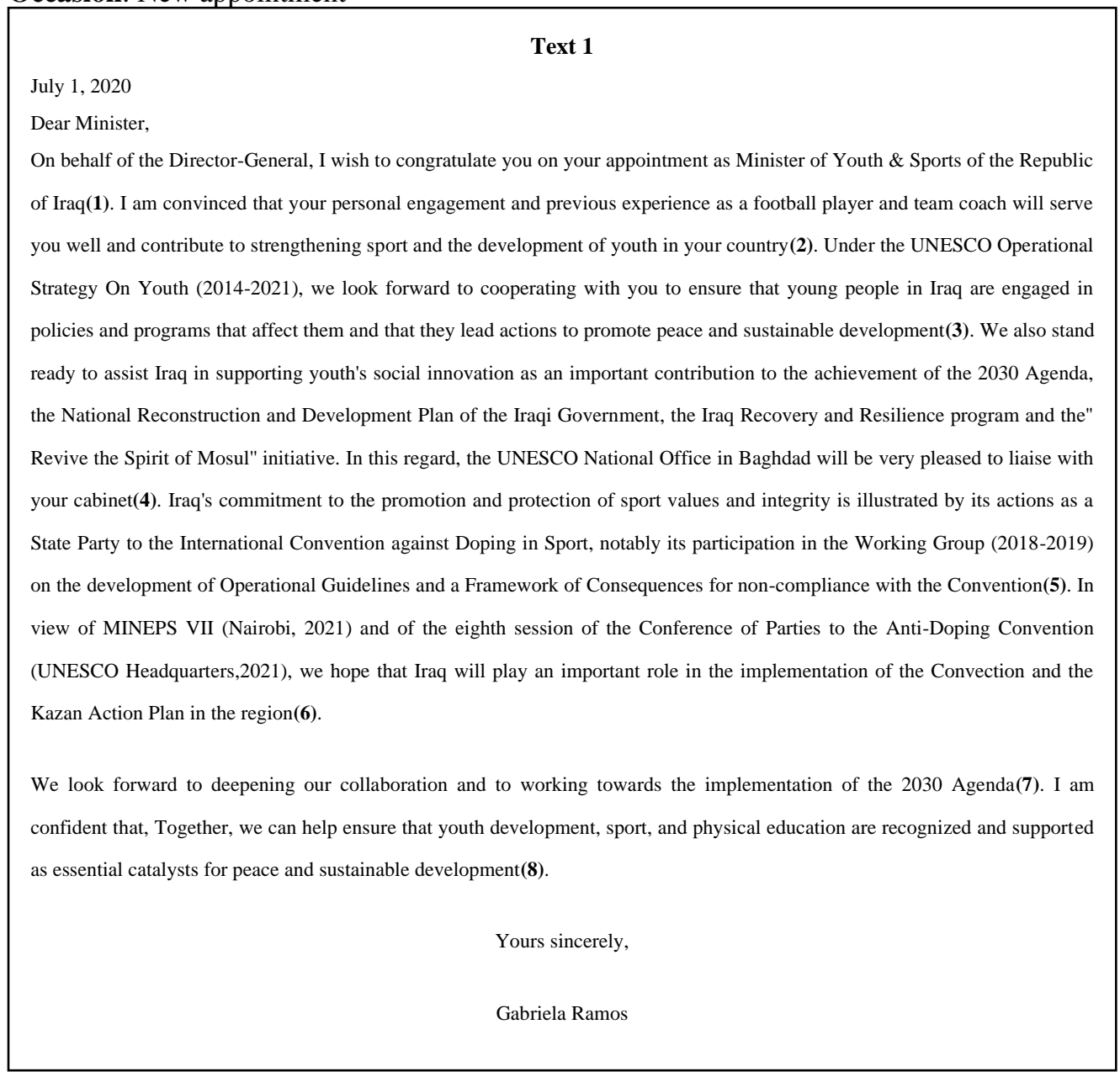


Arab World English Journal (AWEJ) Volume 12. Number 3. September 2021

A Pragma- Stylistic Analysis of Formal Congratulatory Letters

Al-Janabi \& Al-Tememi

\section{Appendix B}

Text (2): a congratulatory letter written by an English high official

Sender: Mr. Donald J. Trump

Addressee: Mr. Barham Salih President of the Republic of Iraq

Date: December 21, 2020

Occasion: Nowruz holiday

\section{Text 2}

December 21, 2020

Dear Mr. President,

On behalf of the American people, I wish you and the people of Iraq a happy Nowruz(1). This is a special holiday of peace and renewal for all(2). This year the holiday has even greater significance, as our countries work to bring peace and stability to $\operatorname{Iraq}(3)$.

We have made great progress together against ISIS, and I look forward to new opportunities to build our economic and security relations with your government(4).

Sincerely,

Donald J. Trump.

\section{Appendix C}

Text (3): a congratulatory letter written by a high Arabic official

Sender: Mr. Muhammad Ali Al-Hakim, Minister of Foreign Affairs of the Republic of Iraq Addressee: Sheikh Khalid bin Ahmed Al Khalifa, Minister of Foreign Affairs of the Kingdom of Bahrain

Date: August 2019

Occasion: of the blessed Eid Al-Adha

Text 3

$$
\begin{aligned}
& \text { سمو الثيخ خالد بن محمد آل خليفة المحترم } \\
& \text { وزير خارجية مملكة البحرين }
\end{aligned}
$$

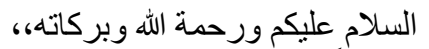

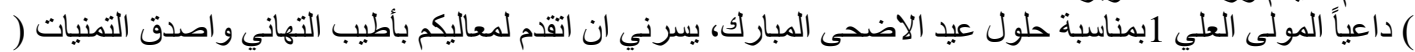

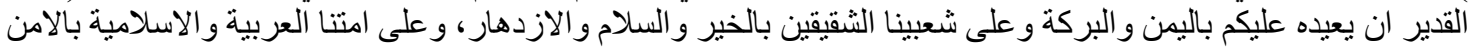

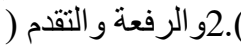

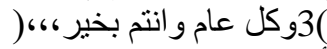$$
\text { أخوكم محمد علي الحكيم }
$$$$
\text { وزير خارجية جمهورية }
$$

العراق

بغداد_آب2019 
Arab World English Journal (AWEJ) Volume 12. Number 3. September 2021

A Pragma- Stylistic Analysis of Formal Congratulatory Letters

Al-Janabi \& Al-Tememi

\section{Appendix D}

Text (4 ): a congratulatory letter written by a high Arabic official

Sender: Mr. Othman Ali Farhood Al-Ghanmi, Staff General

Addressee: Mr. Louis Raphael I Saco, the Honorable Patriarch of the Chaldeans in Iraq and the world

Date: January 6, 2016

Occasion: the advent of the glorious Christmas

$$
\begin{aligned}
& \text { Text } 4 \\
& \text { الى السيد لويس روفائيل الاول ساكو المحترم } \\
& \text { بطريرك الكلدان في العر اق و العالم } \\
& \text { م/ تهنئة } \\
& \text { بمناسبة قرب حلول أعياد الميلاد المجيد نتقدم بأزكى التهاني و التبريكات (1) سائلين المولى - جل في علاهـ ان } \\
& \text { يعيد هذه المناسبة على بلدنا العزيز باليمن و الخير و البركات (2) مع تمنياتي لشخصكم الكريم بموفور الصحة } \\
& \text { و السعادة (3). } \\
& \text { الفريق أول الركن } \\
& \text { عثمان علي فر هود الغانمي } \\
& \text { رئيس أركان الجيش } \\
& 6 \text { ك } 12016
\end{aligned}
$$

